\title{
Cracking the Crystal in STS: Marcelo Fetz Talks with Harry Collins
}

\author{
MARCELO FETZ \\ FEDERAL UNIVERSITY OF ESPÍRITO SANTO \\ HARRY COLLINS \\ CARDIFF UNIVERSITY
}

\begin{abstract}
In this interview, Harry Collins and Marcelo Fetz discuss Collins' early work on the importance of tacit knowledge in laboratory research, the revolutionary spirit of early Science and Technology Studies (STS) research, and his concerns about its current intellectual decline which he sees as a result of the popularity of Actor-Network Theory (ANT) approaches and an increasing focus on policy-relevant STS studies. Collins describes how, in the early years of STS, he was part of a group of social scientists, interested in the analysis of scientific knowledge and practices, who immersed themselves in particular research fields, and then used their familiarity with science to develop radical new approaches to the topic. For him, the "interactional expertise" developed in such encounters is a key research tool--STS's most effective means of generating compelling new ways of understanding science and technology — which should not be abandoned in favor of alternative approaches. In his following reflection, Marcelo Fetz considers the unifying conditions that were needed to "crack the crystal of science," and the later problems resulting from the institutionalization of STS.
\end{abstract}

\section{Keywords}

Harry Collins; interview; interactional expertise; STS history

\section{The Sociology of a Laser}

MF Let's start with some of your memories about the science studies. How did you become involved in STS?

HC I became involved in STS before it was called STS of course. If it was called anything it was called "science studies," and I suppose the first thing I wrote, or the first piece of work I did that was related to science studies I did in 1971. This was when I was doing

Marcelo Fetz, Email: marcelo.fetz@ufes.br

2 Harry Collins, Email: collinsm@cardiff.ac.uk

Copyright (C) 2018 (Marcelo Fetz, Harry Collins). Licensed under the Creative Commons Attribution Non-commercial No Derivatives (by-nc-nd). Available at estsjournal.org. 
my master's degree at the University of Essex. This was a taught master with a dissertation at the end, and at the end I decided I wanted to do something on science. I'd been interested in looking at science labs so I did my dissertation on how people learnt to build a new kind of laser called the TEA-laser. This eventually led to a paper that was published in 1974 about this "Transversely Excited Atmospheric pressure" laser (Collins 1974). The paper has had a lot of life: it was reprinted in 1999 I think, with a collection edited out of Harvard. But to understand how I came to write that paper you need to go back further. The crucial book in the whole of my intellectual life is PG Winch's The Idea of a Social Science (Winch 1958). For reasons I won't bother to go into, in 1967 I first came across this book and I started to read this book and I couldn't understand it and I spent a long time reading it. Then, sometime later, I began to understand it and that book has been the foundation for everything I have done ever since. Later, it must have been around 1968, I accidentally picked up Thomas Kuhn's The Structure of Scientific Revolutions (Kuhn 1962), which I found on the shelf of the LSE bookshop. I'd never heard of it and thought, "that looks an interesting title." It was a little hardback, which unfortunately somebody has since stolen from me (please return it if you have it). Because I'd read Winch and, consequently gone back and read the later philosophy of Wittgenstein upon which Winch's book was based, when I read Kuhn and I thought, "oh he's just applying the Wittgensteinian idea of "forms of life" to science-very straightforward." It is easy to understand Kuhn: it's an application of Wittgenstein and Winch to science-that's what I thought. I was thinking about all of these things when I was at Essex doing my master's degree, and so that's when I decided to go and do something more about science. I went and looked at a couple of things in science labs and eventually found these people making this TEA laser. I thought what I would do would be a knowledge transmission network analysis, "information transmission" as the Americans called it. There was work that Americans had done on the transmission of information between medical doctors and I thought I'd do something like that with this TEA laser, to see how people learn to understand how to work with TEA lasers. But the crucial point is, I was going to do it differently: my idea of the transmission of knowledge was informed by this Winchian/Wittgensteinian perspective so I thought of it not as transmission of discrete bits of information but as people learning a language. I had Kuhn in mind as well, they were going to learn the paradigm or the "way of being in the world," as the phenomenologists might say (another set of ideas I was dabbling with), which enabled them to make the TEA laser. So I didn't just ask them what they read and who they spoke to, but I tried to draw out the difference between the people who actually had a laser on their desk that worked and those that had one that didn't work. I was interested in what is it that enabled them to make a laser work, and of course I was very sensitive to the way they'd become socialized into laser building. I was very lucky, it was a very clean result: all the people who had a laser that worked had spent some time in the company of other people who had had a laser that worked, whereas people who had what looked like a laser on their bench that wouldn't work, hadn't spent time in 
the company of people who had a laser that worked. Obviously somebody had to invent this in the first place but once it had been invented the capacity to make a working laser travelled via socialization, not information transmission. So I wrote up this for my little dissertation under the title "The Sociology of the CO2 Laser"- the kind of title that noone had ever seen before. How do you have a sociology of a laser? And then somebody said to me, "where are you going to publish this?" And I was just a student so I said, "publish? Am I supposed to publish?" And they suggested I should try publishing it in Science Studies [now Social Studies of Science]. So I submitted it to Science Studies. And, of course if Science Studies hadn't existed then I wouldn't have sent it there, or maybe anywhere. But there it was, founded by David Edge. David Edge received this paper and I remember meeting him some time and he said to me, "that's great we've finally got a paper where somebody's actually done some empirical work instead of just philosophizing about things." So I felt pretty good. One of the referees, who was Mike Mulkay as I later found out, said, "what this guy's talking about is tacit knowledge." I'd never heard of tacit knowledge but he said this is Polanyi; he's talking about the transmission of tacit knowledge. So then, and that was long after I'd written it, I put in the paper that it was about tacit knowledge and gave it the title "The TEA Set: Tacit Knowledge and Scientific Networks." That was probably a good thing because I then became an expert on tacit knowledge. But in other ways it was a bad thing because it was really a different kind of idea. I had in my head this idea of the spreading the form of life whereas Polanyi is much more concerned with personal understanding and instinct. So the tacit knowledge business has been both good and bad. The paper was published under the tacit knowledge title.

\section{Discovering the Seven Sexes}

MF How has the sociology of a laser become a new field-controversy studies?

HC I decided I would do a PhD that included finishing off the TEA laser study. I should have said that I started to do the PhD before I submitted anything for publication. Before finishing the paper, I went to America and talked to laser scientists there so I could complete the knowledge transmission network from where it started in Canada. For my master's research at the University of Essex I just travelled around the UK, but for the $\mathrm{PhD}$ I also travelled around America and also went to Quebec. I thought it would be interesting to compare the TEA laser study with some bits of science where there was more controversy going on, so I picked a couple of comparative cases, one of which was gravitational waves, another of which was parapsychology-psychokinesis. My official supervisor, Stephen Cotgrove, said I should do another comparison with a theoretical controversy. So I included the theory of amorphous semi-conductors but I could never understand the theory of amorphous semi-conductors. I did about 12 interviews scattered around the USA on the theory of amorphous semi-conductors and I had to abandon it, I just couldn't understand the science. But it was a useful experience because 
when you know what it feels like not to understand you are more confident about what you do understand. The trip was all a great deal of fun. I drove around the USA in an old car. I was driving across Nevada on the way to California to sell the car and go home and I was thinking about how I was going to write it up. I suddenly realized that I couldn't write it up! In the case of the TEA laser the distinction between whether the laser was working or not working was very important because that was how you could tell who had acquired the form-of-life and who had not. You could tell whether the laser was working because it produced a very powerful beam of radiation; you pointed at something and the thing would smoke or burst into flames. With the gravity wave detectors the criterion was missing: you didn't know whether they were working or not. Some people said a working gravitational wave detector should detect gravitational waves like Joe Weber, the pioneer, said he was detecting, and other people said, "no a working gravitational wave detector won't see anything because this apparatus is no good for detection gravitational waves." And I suddenly realized, "hey I have no clear defining criteria for whether this gravitational wave detector is working." And I thought to myself as I drove along, "my goodness I've wasted all this money, my $\mathrm{PhD}$ is a disaster!" "How come I am so stupid as to have made this fundamental methodological error?" The hairs stood up on the back of my neck. And I'm driving along, and I think it took me about 20 minutes...I said, "wait a minute, if I don't know whether it's working, the scientists don't know if it is working either, and that is much more interesting than what I set out to find." My new question was "how do the scientists decide whether the thing is working or not?" And that turned into my second paper which was called "The Seven Sexes" (Collins 1975) and I became quite famous. So for a few years after that I was one of the leaders of the business of the sociology of scientific knowledge. The question you must be wanting to ask is, where does this fit in with Edinburgh? And the answer is it's quite difficult to work out. I knew nothing when I started doing this research, I didn't even know about Robert Merton, and he was a sociologist of science. And I didn't know about Polanyi and tacit knowledge. Somebody must have told me about the Science Studies Unit because I submitted my TEA-laser paper there, but that would have been around 1973-the paper was published in 1974. Insofar as I found out about stuff happening in Edinburgh that grabbed me, it was David Bloor, because David Bloor was having the same ideas about Wittgenstein. Of course, Bloor was doing Wittgenstein's stuff better than me because he was a proper philosopher, I was just doing my interpretation of Wittgenstein from my reading of Winch. So the existence of the Science Studies Unit, the existence of the journal, the existence of a group of people doing stuff meant there was a critical mass, which could turn it into a subject whereas otherwise it would have just been me on my own doing some kind of eccentric stuff. 


\section{Talking Subjects: Interviewing Scientists}

MF How do you think natural scientists received some of your ideas and the ideas of the field as a whole? How they saw the field?

HC In some ways they didn't see us because we were pretty invisible, we were just a small group of crazy academics. So the people we were fighting with at that time were the sociologists of science like the Mertonian School. I can remember having a conversation in 1976, I think it was with Bernard Barber who was at that Cornell meeting, who said to me something like, "the stuff you're doing is great, you've shown us for the first time how to get inside science, all you've got to do is give up all this relativism stuff because that's crazy, and then, as it were, we'll all be together and you've shown us how to get inside science." To me, I didn't want to give up the relativism stuff that was the exciting thing. You know, yeah, we had shown them how to get inside science. My relationships with the scientists were always pretty good. I'm a good interviewer, I'm quite good at talking to people and I had the great advantage that I was really, really interested in the science, I wanted to see what was happening among those scientists. I was disappointed that I couldn't do it with the theory of amorphous semi-conductors but that's why I gave up, because I couldn't understand and really engage with the scientists. But with the parapsychology and gravitational wave physics, I could really engage with the science, I could talk to the scientists about science. I even had "15 minutes of fame" when Nature published a participant-observer correspondence from us about child spoon-benders (Pamplin and Collins 1975:8). So scientists were happy enough to talk to me, but when I published my papers I didn't send them to the scientists, in fact I tried to hide them. Let me jump forward 20 years because in the early 90s, after my excursion into artificial intelligence, I went back and started studying gravitational waves again in a serious way, and I got a grant to do it. I remember telephoning from my office in Bath a guy called Rich Isaacson who was the director of gravitational physics at the National Science Foundation in Washington. I remember getting on the phone to him and saying, "I'd like to come and interview you, if you don't mind, I'm a sociologist and I'm studying gravitational wave physics again." And he said to me, "are you the person who wrote that book called The Golem?" (Collins and Pinch 1993) (which, of course, contains a chapter about gravitational wave physics), and I said, "yes, I'm afraid I am." I thought that was the end of that. But, much to my surprise, he said, "yes, I'd love to talk to you." And I discovered, to my surprise, that those early papers, which I had tried to hide, were actually very well received by the gravitational wave physicists. Maybe they didn't really understand what was being said about science but the point is that they could see that there was somebody who'd really tried to understand the science and had understood it, and who understood the dynamics of a community as it really unfolds, not some formal model of science. I was thinking about Joe Weber in the way that they were. We were drawing different final philosophical conclusions but up 'til the conclusions we were seeing the world-the unfolding of the scientific arguments-in the same way. I've always got on pretty well with the physicists with only occasional problems. Mostly 
those problems have been resolved and led to a deepening relationship. Of course there was the later period called the "science wars," where you had people like Lewis Wolpert and Alan Sokal, and so on, screaming at us. But I always think that did us a great deal of good because it dragged us from being people who nobody knew about into the center of the public stage. Of course we won all the arguments because they didn't really understand anything and the intellectual side of it was never a problem as far as I was concerned. It was so easy to win the arguments.

\section{Wittgenstein and STS}

MF Your ideas have an internal coherence, as I see them. How do you see the connection between your concepts?

HC I see it all of a piece. The same basic thinking, which is always thinking about forms of life; it all comes from the original Winch/Wittgenstein position. Pretty well every idea can be traced back to thinking in that kind of way. I wrote a couple of books about artificial intelligence which was a stream of work which started with the idea that knowledge is socialization not information transmission; the artificial intelligence stuff led me to think about the Turing Test and imitation games. Now I have this huge grant to study imitation games. It's just a very exciting working out of the same set of ideas in different forms. Is the third wave a change? (Collins and Evans 2002; 2007). No, the third wave is also not a change because the definition of expertise is possession of the tacit knowledge belonging to a technical community and that tacit knowledge is acquired through socialization, so an expert is a member of a form of life. So it's the form of life idea that goes through everything.

MF So, Wittgenstein is a central element of your sociology?

HC Yes, absolutely central. Though it is not constraining. We have made a couple of departures from Wittgenstein. For example, my book Changing Order (Collins 1985) deals with change, which Wittgenstein doesn't deal with. And the idea of interactional expertise, which is central to the analysis of expertise, is a departure from Wittgenstein because we separate out the practice and language aspects of forms-of-life which are integral for Winch and Wittgenstein. This is best explained in a 2015 article in Studies in History and Philosophy of Science (Collins and Evans 2015). But nevertheless, without that basic idea nothing would have developed so it is absolutely central as far as I'm concerned. I'm sure there are other kinds of ideas which could have got me to the same place but this has been enough to sustain the whole research program over 45 years or so.

MF How do you see the connection between STS and philosophy of science?

HC I think the first thing I would say if I was writing the history of this is you need to understand what British sociology was like in those days. In those days, British sociology was driven by the agenda of the London School of Economics, was very philosophical. So if you did a sociology degree you did philosophy of science, you learned about Popper and you read this book by Peter Winch, The Idea of a Social Science (1958), and you learned 
to think about Wittgenstein. So I think, if you talked to Bloor and to Barnes, I think you'll find, and me, say, we all have a common background in thinking about Wittgenstein and sociology, the rationality debate. People were always talking about the Azande poison oracle (Evans-Pritchard 1937) - is it rational or isn't it rational? So everybody was thinking philosophically, and I think that's a big input into it, and I think that accounts for the sort of, coincident kind of thinking between say me and Barry Barnes and David Bloor. Of course they were doing it a little before me but I think we all came from the same place. This sort of philosophical common ground fed into the analysis of science. Lakatos was also an important person in those days because Lakatos' book on Proofs and Refutations (Lakatos, Worrall and Zahar 1976) is nice, very nice. It was his PhD thesis, and it fits. And of course Lakatos was crucial for criticizing Popper. I think everybody was a Popperian until you found out how to get out of being a Popperian, and it was Lakatos who showed how to escape it. It all came out of philosophical thinking, and I still publish a lot of stuff in philosophy journals. We haven't reached the modern scene yet, which is completely different. We were interested in asking the same questions about science that the philosophers of science were asking, but we wanted to provide sociological answers. The questions were things like "how do you make truth?" And we said "you make truth by social agreement." Whereas nowadays a lot of people in STS are interested in the environment and making the world a better place and so on, we were not interested in making the world a better place.

MF Strong Program pointed out causality as a central analytical principle. Do you agree with that?

HC Causal explanation? No, I never really understood what that was supposed to mean. I wrote a paper in 1981 where I said I don't know what this means (Collins 1981). Steve Shapin, Donald MacKenzie, they were showing how big P politics could influence what happens on the bench, which was good work. But my response to it was that whenever you find big P Politics influencing what happens on the bench you should try and reduce the influence. Otherwise you're not doing science. This is where the third wave begins because we wanted to say well look this has all gone crazy now, anybody and everybody can be an expert and if you don't have the notion that some people's opinions are worth more than others, and that opinions can be made worthy by observation and expertise, then you are going to live in a dystopia. It has ridiculous consequences. Like when I give a talk at a university, there is no need to invite me and fly me in, just ask the first person that walks past the street. And there is no way of criticizing people who write "scientific" papers purporting to show that tobacco isn't harmful because they are paid to do so by the tobacco companies because what they are doing cannot any longer be said to be unscientific - they are just finding results that fit their views which is perfectly fine. So that led to this notorious third wave paper (Collins and Evans 2002), which seemed to us at the time to be a small thing--a nice little paper which everyone would agree with-but it caused this enormous fuss and resulted us in doing a lot more of that work. To us it did not represent a change of mind, only a change of focus. I have only changed my mind in 
a significant way once in my career and that was in 1981. Before then I thought I was proving philosophical points, that the world really was relative and that scientific knowledge really was socially constructed. Then in 1981 I realized I couldn't prove such a thing and that all I could show is that it is hard to prove that the world is not socially constructed since if you look in detail you do not see Nature revealing some people to be wrong and others to be right-there is too much interpretative flexibility. Of course, Nature may be making things turn out the way they do, it's just hard to see. So then I became what I call a "methodological relativist." Methodological relativism is about the right way to do the sociology of scientific knowledge rather than about what exists. Methodological relativism says that if you want to do the subject properly you should leave Nature out of it and concentrate on the social. The new question is why give more weight to the opinion of scientists and the like than to others when it comes to claims about the natural world? We have a book in progress currently called "Why Democracy Needs Science" (Collins and Evans 2017) which argues that science should be valued because of its moral leadership. Someone will say this is full circle back to Merton but Merton said value democracy because it makes for good science where as we say value science because it makes for good democracy. I would never in the early days have imagined that I would be arguing for the moral excellence of science because that wasn't what needed to be done in the context of the 1970s but it is what is needed now.

\section{Cracking the Scientific Crystal}

MF How do you see the role played by the idea of scientific controversy for the strengthening of the field?

HC I started that with my $\mathrm{PhD}$. There was a rivalry between what we call "controversy studies" and what Latour and Knorr-Cetina later called "lab studies." To study science they went to a single laboratory and stayed in it to see what happened. We, as we turned into the "Bath School," said, "no, you can't do it that way, what you have to do is take your scientific topic--TEA-lasers or gravitational waves--not the laboratory, as the object that you are studying, and this discovery happens across multiple laboratories: you must travel to all of them and see how the argument goes between the laboratories, you won't find out if you sit in only one laboratory because you'll only see what's going on there." Thus, controversy studies became very hot in the early 80s. I think my most important contribution to those early days is the "experimenter's regress," which comes out of studying controversies. So the question is, how does a controversy continue when everybody ought to be able to see what's the truth by doing experiments and repeating experiments? The experimenter's regress shows that even when scientists seem to repeat each other's experiments it still doesn't necessarily settle the matter. That's the most important theoretical input I think. I think that was the crucial "crack in the crystal of science." Without that scientists and others would always have been able to say, "you 
sociologists can say what you like but we know what the truth of the matter is because we can test for the truth by repeating our experiments."

MF Do you see other attempts made by social scientists at that time with the same objective of cracking the crystal of science?

HC Before SSK you could look at science only from the outside, just like the Mertonians did or the philosophers did. You could count up citations, you could count up publications, you could look at Nobel speeches, you could argue about falsification and corroboration, and the normative structure of science, but you couldn't go inside science because it was all thought to be too technical and esoteric and perfect. What the sociology of scientific knowledge did-what we, especially, did was to show how to get inside science so that you could talk about it and analyze it like any other body of knowledge. Bruno Latour I suppose was already in the Salk Institute in the early 70s and he was trying to go inside, but he was doing it in a different way. He was doing it as an anthropologist and, as you probably know, as far as he is concerned you do not have to understand the science to analyze it. He says this, that he doesn't understand what goes on in the Salk Institute he's just observing it like an outsider observer, using his unfamiliarity to confer a powerful stranger's perspective. I don't think you learn much that way. We wanted to understand the science and we wanted to understand the inside of it. So that, to me, is the beginning of it. Of course you could write a different kind of history, if you wrote a different kind of history it would be about institutions, it would presumably be about the Movement for the Social Responsibility of Science. David Edge I expect came out of that kind of institutional background, he set up the Science Studies Unit which was very important. It would be about the Mertonians, with Robert Merton inventing a subject called the sociology of science and the setting up of the Institute for Scientific Information with all the citation counting and co-authorship studies. It would be about the Society for the Social Studies of Science, first meeting in 1976. And without those two institutional bits, the Science Studies Unit and even more so the Society for the Social Studies of Science, I don't know what would have happened to this group. Of course the Mertonians invited the Europeans to that first meeting, which was from their point of view a very big mistake because we took over, intellectually. It was obvious within a year or two that all the intellectual life in this subject was coming from us and Mertonianism was dead. They managed to maintain very strong institutional positions for a decade or so but it was clear what was going to happen, and it has happened. And now of course the modern STS, to its cost, is even more deeply entrenched and stronger than the Mertonians ever were. I say this is to its cost because it has become very resistant to change as we know to our cost. I've often said that if I had been born at the same time as Robert Merton I would have been a Mertonian. One has to be sociological about this. One has to understand the influence of the Second World War. Merton, as I see it, was trying to provide reasons for things that were wrong with fascism, and if you could say, "fascism can't produce good

${ }^{3}$ First meeting of the Society for the Social Studies of Science at Cornell University, 1976. 
science because it's not democratic," that's a pretty good argument for democracy against fascism. It doesn't work but it's a pretty good argument and it would have been good enough for me at the time. The way we argue has to depend on context - it is unsociological not to think so. The third wave grows out of the context of post-modernism: it is a reaction to it. So, for me science and technology studies begins with the sociology of scientific knowledge. The SSK that was invented in the early 1970s, and without which there could be no science and technology studies as we know it because, to return to the metaphor, the sociology of scientific knowledge cracked the scientific crystal.

\section{Creating a "Strong" Community}

MF Today we see us as a community, maybe even sharing a collective "ethos." How was it in the beginning, could you say that there was a sense of belonging in the early days?

HC Not at the beginning. Not when I was doing my first two papers. But it certainly happened fairly soon. We can go to 1976, the first meeting of the Society for Social Studies of Science. We went to Cornell for that very first meeting and there of course was the community of strange Brits who the Mertonians had invited: me, Steve Woolgar, there was Bruno Latour there. Then we suddenly, at that point we felt like a very solid holistic group. That's only '76. It was all squeezed up, squeezed up into a short number of years, but let me tell you they were very long years. This was a huge amount of time, subjectively, for a new student trying to do a new subject, and I think for everybody in the field it was a long time. We were all trying to work out who we were. If you want a chronology I would say clearly the first person to do anything, to think in these terms, was David Bloor, maybe Barry Barnes but certainly David Bloor. I would date the first paper in the sociology of scientific knowledge as being his "Wittgenstein, Mannheim, and the Sociology of Mathematics" (Bloor 1973). I was the first person, as far as I know, to do any empirical work in the sociology of scientific knowledge, and I developed this sort of stream of things independently. Then of course we went through a period after that where, because the Science Studies Unit was big and established and I was at the University of Bath-there were just a couple of us, me and Trevor Pinch and a guy called Dave Travis who was a graduate student - we put a lot of effort into what I would call "product differentiation." You know, we had to say we were different from the Science Studies Unit and the "Strong Program." People used to think at the time "oh they're people from the Science Studies Unit," but we weren't people from the Science Studies Unit, we were doing it our way; we were empirical. In fact, the Science Studies Unit students adopted our way of doing things, Donald MacKenzie and Andy Pickering started doing the empirical kind of studies that we had pioneered; we had shown them how to do. Nowadays of course we, and Bloor, and Mackenzie, and so on are very, very close. We were always very friendly, of course--Steve Shapin turned up as well and was very important. We were always very friendly but at first, we in Bath, felt we had to make some space between us and the Science Studies Unit. We did not have a David 
Edge fronting us. Mike Mulkay was also doing stuff, and had a couple of students, Nigel Gilbert and Steve Woolgar, but I think they came from a different place. Mulkay was very conscious of the Mertonian tradition, writing about norms and counter-norms and things like that. We weren't interested in that, we were interested in the Wittgensteinian approach and just ignored Merton and other traditional approaches to sociology of science-we had that in common with the people from Edinburgh. I would like to emphasize the importance of David Edge because as a leader and as an institution builder I think he was very important, and also he was a person with great courage. Steve Shapin and I were once at a conference, we'd been invited to a conference in Italy, in Pavia, we travelled together, and David Edge was there as well. Steve Shapin and I presented our papers and at this meeting there were some scientists and the scientists were really vile to us. Near the end of the meeting David Edge, and I remember this very clearly, stood up-and remember David Edge was a scientist himself, he was an astronomer--and he gave these people a real dressing-down. He really told them, "no, you've got to start taking notice of these people." He was very, very courageous in that way, and very courageous therefore in establishing space for this kind of thinking among powerful people, and establishing the institution as well. So I think we miss David Edge, I certainly miss him. He was eccentric in some ways, and he was always very, very loyal to his group. But he should not be neglected. He wrote this book on astronomy with Mulkay which is OK, but there were no publications of his that you can point to and say helped to found the field. But in every other way I think he was a very important person. Certainly that community was being built in those early years of the 70s. It's funny to think that those days we were all great friends and we all felt ourselves against the rest of the world, because what we were doing seemed like insanity, especially to the scientists. The early 1970s were certainly the most exciting times of my life academically. We were growing into a new community, everybody was very friendly, we all felt that we were a group who were against the outside world, even though we had some minor differences. And then in the 1980s it all started to fall apart and it's never been the same since.

\section{A Voice in the Wilderness?}

MF As we know it, STS has presented some turning points in the last decades. How do you see the changes introduced in the field?

HC Here's some turning points. First of all, you've got the fact that the people from different perspective started scheming. In the 70s everybody was friends, I can't remember when it ended but probably about the mid-80s. I think in our case it was papers written by Mike Mulkay and his students. It's in this book edited by Knorr-Cetina and Mulkay, 1983, Science Observed (Knorr-Cetina and Mulkay 1983). There's an essay there, by Mulkay, Potter and Yearley, saying Collins' data is unreliable because he's just done a lot of interviews and used interview quotes to suit him, whereas really he should have picked quotes at random or some stuff like this (Mulkay, Potter and Yearley 1983). The thing to 
analyze, according to them, is what people said: the different "repertoires of discourse." It seemed to me to be utterly stupid because if you push along in that direction you next have to ask how you know what the discourses are and you just get into a regress. On the other hand, our whole world is based on meaning of which words are merely illustrative: the world is not made up of words it is made up of meanings and the quotations I use in my papers and books are illustrations of meaning, not data. But it started arguments. Where before there had been unity in the face of the outside world, schisms and arguments started. So that was one turning point and it was no longer such a nice field to be in after that. Another turning point, a huge turning point, which amazed me and in some ways still amazes me, is the extraordinary dominance of Bruno Latour. For a couple of decades Latour came to dominate the field to an astonishing extent, and I still puzzle about that. I think the only way I can understand it is that Bruno found a way to seem to do the sociology of science without understanding any science, which made it a lot easier for a lot of people. Essentially he created a kind of anti-science topic that could become the plaything of the humanities. In the early days, apart from Bruno, everyone felt they had to know a bit of science, or be able to learn a bit of science, to feel that you could write competently about it. So that was always going to keep it a small, esoteric, discipline. But with Laboratory Life (Latour and Woolgar 1979) and its stranger's perspective, and the actor network theory, you didn't have to know any science to pontificate about it. This fed straight into the two cultures tension: humanities people had a way to criticize science without having to understand it first. And what Bruno was responsible for was a huge expansion of the field, an enormous expansion of the field because it was no longer an esoteric field. In one way this was good but in another way it was bad: everything is now too loose. The other thing that contributed to the expansion of the field I have already mentioned; it was the science wars. Then there was another turning point, and I remember one moment that symbolizes it very distinctly. It happened at a meeting of the Society for Social Studies of Science, which I think was in Atlanta. Anyway, it was when Wiebe Bijker was President. I remember Wiebe Bijker sitting up there as President and saying--he used a strange Dutch phrase-“"And so we must go down the boulevard of politics." And I remember putting up my hand and going: "No! We don't want to do politics, we're a scientific society, we should be doing science, not politics. Politics is too easy; science is hard." But it was a voice in the wilderness and the whole movement became very, very political. So that was another turning point that I think was not for the good. So that meant that leadership fell to people like Brian Wynne and Sheila Jasanoff, whose motives are very political: they want to democratize science and stand up for the people against scientists. And again I think this has produced some not very good things. It has taken the insights of the sociology of

" For a critique of Latour, and some of the other early trends in SSK by Harry Collins see Collins, H. M. and S. Yearley. 1992. "Epistemological chicken." In Science as Practice and Culture edited by A. Pickering. Chicago: University of Chicago Press, 301-326; and Collins, H. 2012. "Performances and Arguments" Metascience 21(2):409-418. 
scientific knowledge, which leveled science down, and said well if it's all level, science is just politics by other means. But if science is politics then politics is science and therein lies dystopia.

\section{Navigating Successive Waves}

MF What aspects of this history do you think was exciting, frustrating or useful, what do you think about all the different aspects of STS?

HC I and one or two others were lucky enough to contribute to a scientific revolution--a new kind of understanding of science. It was enormously exciting. I don't think anything can compare with that. What has followed is the working out of that revolution in our understanding. People have taken their different routes and some of these are pretty interesting but they are not radical re-adjustments of our way of being in the world. Rather than setting out my list of preferences-“I like this development and I don't like that"-let's consider where STS as a whole might or might not go. Let us think about the pathologies of academic disciplines and then leave others to reflect on the extent to which STS is falling into the traps or finding ways out of them now that its major revolution is over. One big danger is that disciplines become pathologically self-referential. This has happened with economics, which is now a highly mathematical discipline whose practitioners consider that, in so far as it continually fails to describe the world it is the fault of the world not the economics. With the way disciplines use committees of selfappointed high achievers to assess their products it has become almost impossible to change economics though everyone but those high achievers know that there is something badly wrong. And it is not just the social sciences that suffer from these problems. Lee Smolin has written a book about what he considers to be the pathologically dominant position of string theory in physics (Smolin 2008). STS, it seems to me, needs to avoid this danger. Going back to the early years, Wave 2 had to fight hard to win the subject from the Mertonian orthodoxy and then fight harder to win the institutional positions that went with it. But what we have now is still more firmly entrenched than was Mertonianism. This was not clear to me and my colleagues until we wrote the third wave paper. The reaction to it was vicious, vicious! After the third wave paper I could no longer get papers published in Social Studies of Science--and that was after publishing roughly a paper a year for about 30 years without a hint of a rejection. And I could no longer get grants. We had become professional outsiders. One morning, after a few years of this I walked around the corridors in my department, knocking on Rob Evans' door and the doors of the grad students, saying, "look guys, it looks like you've hitched your wagon to a sinking star, it may be time for you to go and do something else because we're not getting anywhere; think about it." As it happens, when I came into the department the next day they told me they had thought about it and decided it was the most interesting thing going on and they were going to stick with it irrespective of professional success and failure-so we carried on. And after a few years 
we turned the corner. But there is still strong resistance to the third wave stuff in the heartlands of STS, and it still shows up in referee's reports and the refusal of core people in the subject even to acknowledge that the history of science studies can be divided into eras and even to write the word "wave." It is the wider world that has taken up third wave thinking. So to that extent, the third wave has escaped from pathological selfreference but from where we stand it seems that the heartlands of the subject may not have done so. To reflect on my own experience, once more, it is a huge thrill when one discovers one's work is found useful by people outside of one's own narrow disciplinary colleagues. I am delighted that gravitational-wave scientists sometimes cite my books when they want to draw non-specialists' attention to a technical issue such as "blind injections," when a new Director of the Laser Interferometer Gravitational-Wave Observatory told me that he would not have got the job if he had not read my book and when physical scientists in other fields tell me that the Gravity's Ghost (Collins 2013) helps them to understand the "big science" they manage and that they have recommended it to their colleagues. I am delighted that the software testing community seems to have absorbed my work on artificial intelligence and tacit knowledge into their world and that they invite me to give keynote lectures, and so on. I hope STS practitioners will value anything that releases the discipline from narrow self-reference and worry if they do not find such straws in the wind. This is not the same as setting out to create impact, it is just saying "watch out for indicators that show the field is not unhealthily self-regarding."

MF Is the STS political turn an example of this set of problems?

HC Another pathology is single-interest politics. British sociology of the 1960s was normatively Marxist: you were no-one unless you were a Marxist. In STS these days there seems to be a similarly powerful environmentalism: if you are on the side of the environment you are OK but you'd better watch out if you want to treat GMOs symmetrically. It is a pathology when a discipline becomes political, whatever the content of the politics, because the crucial thing for a healthy discipline is that anyone should be able to support pretty well any position even if it is only as devil's advocate. The point about academic arguments is that they should start from the best possible account of what they are opposing - they should start from within the opposition's point of view and work outward from there to show, if they can, why that point of view is wrong. Defeating others arguments should be made as hard as possible, not as easy as possible. On the other hand, the point of political arguments is to diminish the credibility of the opposition by any means and presenting the opposition's viewpoint fairly does not make sense; one wants to defeat the opposition quickly and efficiently. If a discipline develops a normative political stance it becomes very difficult to give a fair hearing to the other viewpoint. People get lazy-it is far easier to play to an audience of like believers than to produce a complex argument or to discover and present a new idea whose grounds of success is the idea itself not the political stance it aligns with; Max Weber explained some of this in his essays on science and on politics as professions. In STS the danger is enhanced because of where its own intellectual stance on the nature of science 
takes it: if you believe science is a continuation of politics by other means then you can also come to believe that when you are doing politics you are doing science. This can make arguers ruthless, dropping their respect for the ways of arguing that have traditionally been taken to lead toward the truth - that is ways of arguing that start from taking the others viewpoint as seriously as possible rather than ways of arguing that distort the other's viewpoint so as to better reach out to an audience. My own view is that when the crowd is on your side that is the time to worry about whether you are taking the easy political route rather than the difficult science-like route. In the same way I have always distrusted too much charm. This means my approach to academic life tends to be the opposite to that which goes together with the Latourian notions of "interessement" and "enrolment." Thus, I once pointed out to Rob Evans that my approach is to make people dislike me so that if I can convince them I am right it must be because of the force of argument not the force of my charming personality. Rob Evans remarked that I had succeeded in the first part of the project but not necessarily in the second! In what I have been saying there is also an assumption that STS is science-like. If you think that STS should be a science then becoming a humanity is another pathology because humanities stress the interpretative license of the audience--they try to draw the audience into a view, or offer the audience a variety of views, rather than take it as their job to demonstrate to an audience that only one view is correct. This means performance becomes more important than argument-argument in the old-fashioned sense. Fashionableness becomes a criterion of excellence. I think STS needs to encourage its practitioners to be unfashionable and unpopular and try to convince by force of argument rather than charm and rhetoric. This is what a science must aspire to irrespective of whether it can be achieved. It is so much easier to strike a political pose and to be politically on the right side than to invent a new scientific principle. Scientific disciplines and their practitioners must guard against doing the easy, fashionable, thing.

\section{Cracking the Crystal in STS}

\section{By MARCELO FETZ}

In this interview, Harry Collins presents a collection of moments from the last five decades, during which science and technology studies (STS) explored scientific knowledge and practice in a new and radical fashion. He gives the "history of how we get inside science," and describes how the work of his generation of STS researchers "cracked the crystal of science." In this short 
commentary, I use previous science studies debates about the nature of our field to examine this metaphor. I hope to show how important such debates were to the earliest science studies practitioners, as well as how they can benefit STS today.

The 1960s-when contemporary STS was born--was a period of important cultural change in Western Europe and Northern America. In the first handbook of the Society for Social Studies of Science, Ina Spiegel-Rosing makes a link between STS's new way of seeing science and wider social changes (Spiegel-Rosing 1973). She argues that STS is humanistic, relativistic, reflexive, de-simplifying, and normative: a culturalistic approach influenced by countercultural movements. Proponents intended to put the actor back into science and break down the boundaries between what was considered internal and external to science. Collins' contribution to the nascent STS project involved studying the processes that actually took place in scientific laboratories, largely by talking to scientists about their work. He began with a study of the TEAlaser and then moved on to the topic of gravitational waves (Collins 1974). Using ideas about the role of systematic procedure and the repetition of experiments, he wrote, amongst other things, about the importance of tacit knowledge, the nature of expertise, and the experimenter's regress. This research contained a significant empirical element that is reflected in the name given to the Bath School approach, the Empirical Program of Relativism (EPOR). Like many other STS researchers, Collins saw scientific controversies as a core research topic for STS, since they are a fertile way of studying how scientists construct knowledge (Pinch and Collins 1993).

"Cracking the scientific crystal" provides a striking metaphor for the changes that occurred in the 1970s when STS questioned the heroic image of science that had dominated previous accounts. According to STS, scientific knowledge should not be treated as intrinsically privileged, nor seen as being beyond the analytic capabilities of social science. The image of a cracked crystal reflects the revolutionary spirit of the first generation of STS scholars and their critical perspectives on science. The "scientific crystal" was made of very strong materials and a significant amount of collective work was required to crack it. New concepts, methodological tools, and crucially, a community of social scientists with common interests in the analysis of science, were required to break open science.

Collins highlights key aspects that allowed STS to crack the scientific crystal, and they all rely on some form of unity: a philosophical unity within STS; unity on the part of STS's opponents within the social sciences (due to the dominance of structural-functional theory in sociology and critical positivism in philosophy); and a unity of target (science and technology offered a new theoretical project with space for innovation); and social unity (a small community meant the possibility of closer interaction). This account accords with other descriptions of this period, when STS researchers saw themselves as living in exciting times and fighting against the dominant images and understandings of science and technology - both in society and within the existing social sciences. But Collins argues that this unity did not last long. Despite the early successes of STS researchers, unity dissipated before the revolutionary task of cracking the crystal of science was completed.

The period following this dissolution is when, I think, we start to see the core components of current STS approaches develop. The field is now characterized by the coexistence 
of different analytical perspectives, including the EPOR, the Strong Program in the sociology of scientific knowledge, Actor-Network Theory (ANT), and co-productionist analyses of science policy. Furthermore, as scholars such as Sheila Jasanoff have argued, the thing we call science studies has an intrinsic political component (Jasanoff 1999). Indeed, the political dimension of STS was so important to Salomon that he argued that the study of science, technology, and society was "born of war" (Salomon 1973, 43). Together, these threads within past and current STS represent a cluster of competing-and, at times, entirely incompatible-analytical frameworks.

Such considerations lead back to the issue of unity. I agree with Collins about its importance in the initial stages of breaking open the crystal of science. But I think that the unity he describes was contingent on the four factors outlined above, (namely, philosophical unity, social sciences unity, target unity, and social unity) and the disunity that has succeeded it has been crucial for later generations of STS researchers, assuring the diversity of perspectives that currently exists within the field. This lack of consensus is both an inevitable outcome of the field's status as a social science and an important reason for its past achievements.

Collins, like many of our interviewees, is concerned with how to make STS generate compelling new ways of understanding science and technology again and again. He believes that the classical methods of STS have been diverted from their original purpose: the study of scientific knowledge and practice. As I understand him, he is not trying to reduce the diversity of approaches used within STS. Rather, he is worried that specific approaches, even when not used to analyze science and technology, are framing the future of the whole field, creating an imbalanced institutional environment that favors certain work and scholars. The growing popularity of ANT and the political turn in the field are in his opinion linked to the relative intellectual decline of STS in recent years. Both of these approaches, Collins argues, are receiving disproportional academic attention given their limited capacity for analyzing science, and, thereby, carrying on with the project of cracking the crystal of science. ANT, he argues, uses detachment as an analytical procedure, focusing on the "strangeness" of scientific practices, when, in his opinion, STS needs the opposite: familiarity with scientific ideas, arising from a deep immersion in the particularities of science.

For Collins, "interactional expertise" (Collins and Evans 2002) is not only a sociological concept developed to describe a type of social relation; it is also a research tool for those interested in continuing to crack the crystal of science (Collins 2013). Policy-oriented STS research presents problems, he says, partly because political analysis is something that STS scholars often do badly. More importantly for Collins, the practice of science and technology is done with different aims from that of politics, and so its decisions should be taken in separate spheres using different forms of expertise (Collins and Evans 2002). Collins' disagreements with ANT and coproductionist methodologies are well known in the field, and I agree with him that their institutional impact on other approaches--such as competition for research funding and opportunities for publication-deserves more attention.

In the final part of our talk, Collins returns to consider the future of STS. He argues that the field-or at least large parts of it--has lost the momentum required to continue cracking the 
crystal of science. Contemporary STS, he argues, has become institutionalized, and instead of developing and promoting radical new ways of understanding science and technology, researchers put their energies into gaining academic positions and prestige. I agree with him that institutionalization has led to a negative "disciplinary turn" in the field, removing the radical vein present in the early days. Furthermore, this problem is linked to the previous one, the relative predominance of ANT and co-productionist approaches, which has reduced the diversity of ideas developed within in the field. The shared epistemological and methodical commitments of early STS allowed it to develop a diverse set of new approaches to the study of science and technology. However, as the field developed and expanded, it became increasingly fragmented and, Collins argues, eventually began to homogenize around ANT and co-productionist perspectives. Thus, perhaps some of the key challenges STS currently faces are linked to this restabilization--of our own social scientific crystal--and we now need to think about how to crack that new crystal.

\section{Author Biography}

Harry Collins is Professor of Sociology at the School of Social Sciences at Cardiff University, Wales and director of the Centre for the Study of Knowledge, Expertise and Science (KES). Throughout his career he has held positions as visiting professor and affiliated research scholar at University of California, San Diego, Cambridge University, Cornell University, the Max Planck Institute, and the California Institute of Technology. Collins is a proponent and co-founder of the Bath School of the Sociology of Science, which emphasized the microsociological study of laboratory experimentation. He is perhaps best known for his work on various kinds of expertise and on the sociology of gravitational wave physics, a topic on which he has written extensively for more than 35 years. Collins has received awards including Book of the Year, Emory and Henry College, 1994-95, and the Robert K. Merton Book Prize, American Sociological Association in 1995 for The Golem: What You Should Know about Science (Pinch and Collins 1993), and the J.D. Bernal Award, Society for Social Studies of Science in 1997, for contributions to the social studies of science. He was elected Fellow of the British Academy in 2012.

\section{Author Biography}

Marcelo Fetz is professor of sociological theory at the Federal University of Espírito Santo (Brazil). He holds a PhD in sociology from the State University of Campinas (UNICAMP) and he is interested in the fields of social studies of science and history of science.

\section{References}

Bloor, D. 1973. "Wittgenstein and Mannheim on the Sociology of Mathematics." Studies in History and Philosophy of Science 4(2):173-91. 
Collins, H. M. 1974. "The TEA Set: Tacit Knowledge and Scientific Networks." Science Studies 4:165-186.

Collins, H. M. 1975. "The seven sexes: a study in the sociology of a phenomenon, or the replication of experiments in physics." Sociology 9(2):205-224.

Collins, H. M. 1981. "What is TRASP: The Radical Program as a Methodological Imperative." Philosophy of the Social Sciences 11:215-224.

Collins, H. M. 1985. Changing Order: Replication and Induction in Scientific Practice. London: Sage.

Collins, H. M. 2012. "Performances and Arguments." Metascience 21(2):409-418.

Collins, H. M. 2013. Gravity's Ghost and Big Dog: scientific discovery and social analysis in the twentyfirst century. Chicago: University of Chicago Press.

Collins, H. M. and R. Evans. 2002. "The Third Wave of Science Studies: Studies of Expertise and Experience." Social Studies of Science 32(2):235-296.

Collins, H. M. and R. Evans. 2007. Rethinking Expertise. Chicago: University of Chicago Press.

Collins, H. M. and R. Evans. 2015. "Expertise Revisited I: Interactional Expertise." Studies in History and Philosophy of Science 54:113-123.

Collins H. M. and R. Evans. 2017. Why Democracies Need Science. Cambridge, UK; Malden, MA: Polity Press.

Collins, H. M., and T. J. Pinch. 1993. The Golem: What Everyone Should Know about Science. Cambridge: Cambridge University Press.

Collins, H. M. and S. Yearley. 1992. "Epistemological chicken." In Science as Practice and Culture, edited by A. Pickering. 301-326. Chicago: University of Chicago Press.

Evans-Pritchard, E. E. 1937. Witchcraft, Oracles and Magic among the Azande. Oxford: Clarendon Press.

Jasanoff, S. 1999. "STS and Public Policy: Getting Beyond Deconstruction." Science Technology Society 4(1):59-72.

Knorr-Cetina, K., and M. J. Mulkay. 1983. Science Observed: Perspectives on the Social Study of Science. London: Sage.

Kuhn, T. S. 1962. The Structure of Scientific Revolutions. Chicago: University of Chicago Press.

Lakatos, I., J. Worrall, and E. Zahar. 1976. Proofs and Refutations: The Logic of Mathematical Discovery. Cambridge: Cambridge University Press.

Latour, B., and S. Woolgar. 1979. Laboratory Life: The Social Construction of Scientific Facts. Beverly Hills: Sage Publications.

Mulkay, M. J., J. Potter, and S. Yearley. 1982 "Why an Analysis of Scientific Discourse is Needed" In Science Observed: Perspectives on the Social Study of Science, edited by K. Knorr-Cetina, and M. J. Mulkay. 171-203. London and Beverly Hills, CA: Sage.

Pamplin, B. and H. Collins. 1975. "Spoon Bending: an Experimental Approach." Nature 257:8.

Pinch, T. J. and H. M. Collins. 1993. The Golem: what Everyone Should Know About Science. Cambridge: Cambridge University Press.

Salomon, J. 1973. "Science Policy Studies and the Development of Science Policy" In Science, Technology and Society: a Cross-Disciplinary Perspective, edited by I. Spiegel-Rosing, and Solla-Price, D. 43-70. London and Beverly Hills: Sage. 
Smolin, Lee. 2008. The Trouble with Physics: The Rise of String Theory, the Fall of a Science and What Comes next. London: Penguin.

Spiegel-Rosing, I. 1973. "The Study of Science, Technology and Society (SSTS): Recent Trends and Future Challenges." In Science, Technology and Society: a Cross-Disciplinary Perspective edited by I. Spiegel-Rosing and D. Solla Price. London and Beverly Hills: Sage.

Winch, P. 1958. The Idea of a Social Science, and Its Relation to Philosophy. London: Routledge \& Kegan Paul. 